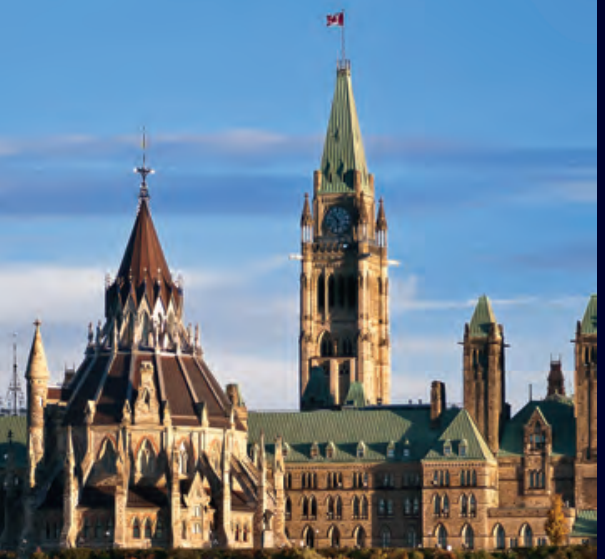
. $2 \%$
tit.

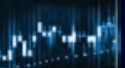 3
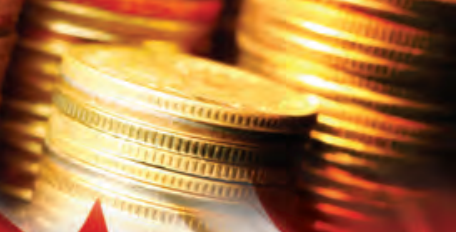

\author{
COMMENTARY \\ NO. 493
}

\section{Off Target: Assessing the Fairness of Ottawa's Proposed Tax Reforms for "Passive" Investments in CCPCs}

institut C.D. HOWE institute

Business owners who save for retirement or reinvestment inside an incorporated firm are no better off after tax than other savers in RRSPs or TFSAs. Ottawa has better alternatives to achieve fairness.

Alexandre Laurin 


\section{THE C.D. HOWE INSTITUTE'S COMMITMENT TO QUALITY, INDEPENDENCE AND NONPARTISANSHIP}

\section{ABOUT THE AUTHOR}

Alexandre Laurin is Director of Research at the C.D. Howe Institute.
Commentary No. 493

October 2017

Fiscal and Tax Policy
The C.D. Howe Institute's reputation for quality, integrity and nonpartisanship is its chief asset.

Its books, Commentaries and E-Briefs undergo a rigorous two-stage review by internal staff, and by outside academics and independent experts. The Institute publishes only studies that meet its standards for analytical soundness, factual accuracy and policy relevance. It subjects its review and publication process to an annual audit by external experts.

As a registered Canadian charity, the C.D. Howe Institute accepts donations to further its mission from individuals, private and public organizations, and charitable foundations. It accepts no donation that stipulates a predetermined result or otherwise inhibits the independence of its staff and authors. The Institute requires that its authors publicly disclose any actual or potential conflicts of interest of which they are aware. Institute staff members are subject to a strict conflict of interest policy.

C.D. Howe Institute staff and authors provide policy research and commentary on a non-exclusive basis. No Institute publication or statement will endorse any political party, elected official or candidate for elected office. The Institute does not take corporate positions on policy matters.
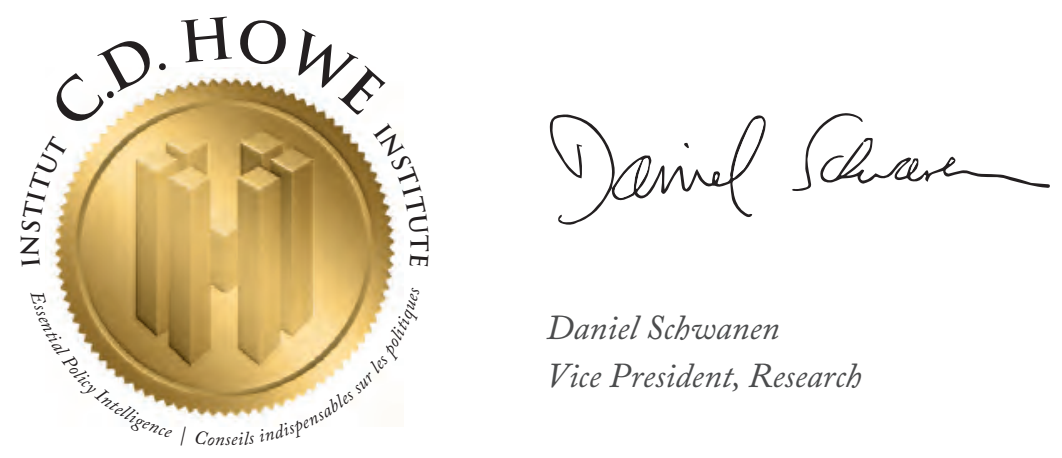

Daniel Schwanen

Vice President, Research 


\section{THE STUDY IN BRIEF}

In July 2017, the Department of Finance launched consultations on a series of tax proposals affecting owners of Canadian-Controlled Private Corporations (CCPCs). The proposals on the treatment of "passive income," from investments such as equities and government bonds, have attracted particular controversy.

The proposed regime would end passive investment income-tax refundability for CCPCs - ie., taxes paid on investment income in a CCPC would no longer be tracked and refunded upon dividend payments. Although there are other versions of proposed changes, this is seemingly the one the government favours. Private corporations - and by extension their owners - would be taxed on their passive investment income on the same basis as if they were individual investors in fully taxable accounts. There would be diminished incentives to defer business consumption, and less income and business saving available for spending on capital equipment. The same is true of small business income retained for personal purposes - there will be greater incentives for immediate personal consumption of business income rather than saving it for retirement or other purposes.

But is the current system inequitable? Our tax simulations show, overall, it is not - when benchmarked against the tax treatment afforded to personal retirement savings. Saving for retirement in tax-assisted plans - on a "consumption-equivalent" tax basis with a steeply graduated tax rate structure - is widely accepted in principle and in practice, because such treatment does not discourage saving as a pure income tax would do. Considering that additional administration, accounting, and tax compliance costs need to be incurred in corporate accounts, one could reasonably conclude that passively reinvested smallbusiness earnings receive a tax treatment similar to that of RRSP/TFSAs in a variety of possible portfolio compositions. Besides, successful businesses earning income above the small-business threshold enjoy no significant tax "advantages" on passively reinvested earnings.

As laid out, these proposals risk delivering a blow to the retirement planning of many small business owners, not to mention their potential negative impacts on entrepreneurship and risk taking. Further, the playing field with respect to tax-assisted saving opportunities is already largely unequal. Outdated current tax rules allow career defined-benefit (DB) pension plan participants, particularly in the public sector, to end their careers with tax-assisted retirement wealth worth multiples of that practically achievable in RRSPs.

If the government proceeds with changes along the lines it has outlined, fairness suggests that it should level the playing field so business owners have tax-assisted retirement saving opportunities comparable to those available to most public-sector employees in DB plans and Members of Parliament. The most ambitious reform would establish a lifetime accumulation limit of personal tax-assisted savings, in lieu of the current system of annual limits. A lifetime accumulation limit would ease the transition to the new proposed regime, and provide needed contribution flexibility and room to everyone, including small business owners, to accumulate sufficient retirement wealth.

C.D. Howe Institute Commentary $($ is a periodic analysis of, and commentary on, current public policy issues. James Fleming edited the manuscript; Yang Zhao prepared it for publication. As with all Institute publications, the views expressed here are those of the author and do not necessarily reflect the opinions of the Institute's members or Board of Directors. Quotation with appropriate credit is permissible.

To order this publication please contact: the C.D. Howe Institute, 67 Yonge St., Suite 300, Toronto, Ontario M5E 1J8. The full text of this publication is also available on the Institute's website at www.cdhowe.org. 


\section{A vigorous debate has erupted over Ottawa's proposed changes to the way it taxes income from privately owned, incorporated businesses in Canada. Small business owners, incorporated professionals, and economists have all weighed in.}

The debate was sparked in July 2017, when the Department of Finance launched consultations on a series of tax proposals affecting owners of Canadian-Controlled Private Corporations (CCPCs). The proposals include restrictions on how dividend income is attributed to family members of the business owner, restrictions on the realization of capital gains through share sales to family members, and changes to the tax regime governing the treatment of corporate income from so-called "passive" investments in, for example, the stock market or government bonds (Canada 2017).

The stated objective of the tax proposals with respect to passive investment income earned by CCPCs is to provide "fairness" between employed individuals and business owners earning business income through private corporations. However, this Commentary shows that:

(i) CCPC income taxed at the general tax rate and reinvested passively in the corporation enjoys no significant tax advantages over other saving options; and

(ii) business owners earning income taxed at the small-business tax rate and saving it in the corporation for future personal consumption enjoy a tax treatment pretty much on par with others saving through an RRSP or a TFSA.

The proposals on passive income have attracted particular controversy, much of it explicitly or implicitly a debate over whether a comprehensive, integrated, personal and corporate income baseline is a good model for tax policy. However attractive in theory - and opinion is divided on that - this benchmark is a poor basis for tax policy and judgements about fairness. Benchmarking, instead, against the tax treatment afforded to retirement saving is more useful. This approach makes clear that mitigating the impact of cascading taxes through the double- or triple-taxation of saving by deferring tax inside a company is not dissimilar to the way retirement savers can avoid tax cascading in Registered Retirement Savings Plans (RRSPs) or Tax Free Saving Accounts (TFSAs).

Saving for retirement in tax-assisted plans on a consumption-equivalent tax basis - with a graduated tax rate structure - is widely accepted in principle and in practice, because such treatment does not discourage saving as a pure income tax would do.

The proposed reforms would in effect confine many business owners to using their available personal RRSP contribution room in order to taxeffectively save for retirement. ${ }^{1}$ But annual RRSP contribution limits are a particular problem for small business owners. Small business owners are at particular risk of having insufficient accumulation of RRSP room because they are at a greater risk of

The author thanks William Robson for his assistance in drafting this Commentary, as well as William Molson, Angelo Nikolakakis, James Pierlot, Daniel Schwanen, Jeffrey Trossman, members of the Fiscal and Tax Competitiveness Council, and anonymous reviewers for comments on an earlier draft.

1 Other options exist, notably the establishment of an Individual Pension Plan. See footnote 18 for some of the limitations as they apply to entrepreneurs. 
having incurred investment losses and bankruptcies, experienced periods of highly fluctuating incomes, or made RRSP withdrawals before retirement to fund capital investments in their businesses.

They may also have planned their affairs under the current regime to take full advantage of the flexibility that combining their personal and business savings offers with respect to cost-effectively funding future business-related investments. For these reasons, they could now be caught under the proposed regime with less contribution room than they could have accumulated, in retrospect, had they planned their affairs differently. Further, the proposed regime would encourage small business owners to maximize the use of personal tax-assisted saving vehicles to accumulate savings outside the business whether they are intended for businessrelated or personal purposes. But RRSPs are a poor substitute to retained earnings for savings that ultimately serve a business purpose because early withdrawals from these accounts create a permanent loss of retirement saving room.

As laid out, these proposals risk delivering a blow to the retirement planning of many small business owners, not to mention their potential negative impacts on entrepreneurship and risk taking. Further, the playing field with respect to tax-assisted saving opportunities is already largely unequal. Outdated current tax rules allow career defined-benefit (DB) pension plan participants, particularly in the public sector, to end their careers with retirement wealth worth multiples of that practically achievable in RRSPs.

If the government proceeds with changes along the lines it has outlined, fairness suggests that it should level the playing field so business owners have tax-assisted retirement saving opportunities comparable to those available to most public- sector employees and Members of Parliament who have relatively generous DB pension plans. The most ambitious reform would establish a lifetime accumulation limit of tax-assisted savings, in lieu of the current system of annual limits, as was suggested by Pierlot and Siddiqi (2011). The limit would be set to match the savings opportunities of those currently enjoying the most generous pensions, so that anyone willing to fund for themselves an equivalent arrangement could do so, including small business owners.

\section{THE POLICY OBJECTIVES BEHIND THE PROPOSED REGIME}

Finance Canada's white paper (Canada 2017) contends that the current rules governing the tax treatment of "passive" income - income earned from investing retained earnings within a private corporation, as distinct from the "active" income generated by the business's main activity - gives an unfair tax advantage in particular to small business owners compared to other investors. In a number of situations, individual taxpayers investing their after-tax employment income into a personal taxable account will end up paying more taxes on that "passive" income than a small business owner earning the same amount of income but reinvesting it passively in a corporate taxable account. The white paper states that the tax system should not incentivize business owners to retain earnings within a corporation if the goal is to hold "passive" investments for future personal consumption. ${ }^{2}$ Recent increases to the top personal income tax rate have widened the gap between business tax rates and the top personal rate, increasing the potential value of the tax deferral available on retained earnings in a business, thus likely encouraging small business owners to leave money in their companies.

2 The white paper suggests that income would be classified as "active" or "passive" based on the existing definition applicable to CCPCs. 
The difference in tax burden arises, first, because earnings derived from carrying on a business and retained in a corporation are initially taxed at a much lower rate (especially if it qualifies for the small business tax rate) than income from employment or an unincorporated business earned by top marginal tax rate earners. Hence, business owners are left with higher initial investment capital and thus greater investment income potential. Retained earnings will eventually bear the full tax burden once distributed to shareholders so taxes are only deferred in time - but the current system under which all or part of the taxes on investment income earned in a CCPC is refunded to the corporation make their tax treatment advantageous, in some cases, compared to income from investments in taxable personal accounts.

\section{THE CURRENT AND PROPOSED REGIME FOR PASSIVE INVESTMENT INCOME}

The objective of the proposed regime for passive income is to remedy the perceived unfairness between individuals investing outside and inside CCPCs.

\section{Personal Investment Income Tax Regime}

Individuals saving in taxable accounts must pay personal income taxes on their employment income, invest the after-tax proceeds and pay additional taxes on the investment income. Personal saving is thus taxed twice or more: first, when the source capital is earned; again when the savings produce investment income; and again if the after-tax investment income is reinvested and produces more income. This cascading of taxes on saving encourages consumption in the present, and distorts choices by making investment in assets such as principal residences which are subject to less cascading - more attractive than they otherwise would be.

People can also avoid this cascading by investing in a registered account, such as an RRSP or TFSA, in which there is no tax assessed on the investment income. In a TFSA, income taxes are paid before money is deposited in the account, thus earnings are effectively taxed only once, no matter when they are withdrawn and spent. In an RRSP, income taxes on the investment principal are deferred until withdrawal of funds, at which time the deferred taxes will be paid. If there is no change in the applicable personal tax rate through time, the RRSP and the TFSA will yield effectively the same wealth available for consumption, which would have been taxed only once. This, in effect, is consumptionequivalent taxation with a graduated rate structure.

The fairness argument put forward to introduce the proposed regime implicitly adopts the ideal of a comprehensive income tax, in which all annual increments in net worth should be taxed, as a baseline. But there is no unanimity among experts and economists about ideal baselines, and certainly no consensus about the comprehensive income tax. Although the comprehensive income tax is influential in tax policy discussions, and inspires exercises such as the Department of Finance's annual cataloguing of tax expenditures, its drawbacks make it an abstraction (Robson and Laurin 2017). All real-world tax systems exempt many forms of saving and returns on saving from tax. This is certainly true in Canada: Kesselman and Spiro (2014) estimate that less than 20 percent of personal investment income is now subject to income tax, the rest being sheltered. Therefore, the current personal tax system is much closer to a consumption-based system than to a comprehensive income tax. ${ }^{3}$

3 And although taxable personal investment income tends to be concentrated at the top of the income distribution, the bottom 90 percent of workers ordered by employment income still earn about two-thirds of all taxable personal investment income (Thivierge and Laurin 2017). 


\section{The Corporate Passive Investment Income Tax Regime}

When a business activity generates income directly, the active income is taxed once at the corporate level, then again at the personal level when it is distributed to shareholders in the form of dividends. To avoid cascading taxation of the same income at both the corporate and personal levels, an integration mechanism permits dividends to be taxed at a lower effective rate ${ }^{4}$ than the applicable personal income tax rate, making the total tax applicable on the active business income approximately equal to the tax rate paid on personal income. In essence, if integration were perfect (it is not) a business owner would be more or less indifferent as to whether the active business income is taxed first in the corporation and again when distributed as dividends, or whether the business income is taken as a salary.

Business income not immediately paid out as dividends, or spent on capital equipment or other business purchases, stays in the company. These retained earnings may be "passively" invested in shares, bonds, or real estate. ${ }^{5}$ The passive investment income earned on these assets - interest and rental income, dividends, and capital gains - attacts high corporate income tax rates, ${ }^{6}$ but a portion of these corporate-level taxes accumulate in a special accounting pool $^{7}$ and may be refunded to the corporation when the income is paid out and taxed as dividends at the personal level to avoid double taxation of the same income. ${ }^{8}$

Therefore, the tax system for private corporations is, in effect, broadly taxing business income on a consumption basis. Business consumption through purchases of equipment and capital attracts no tax. ${ }^{9}$ Business income used for passive investments gets partial tax relief through the refundable tax. And income distributed to shareholders for personal consumption attracts individual tax.

In practice, shortcomings in the mechanisms to integrate personal and corporate taxes create significant differences between the corporate tax regime and elements of the personal tax system that make the latter resemble a consumption tax, such as RRSPs. The refunds of passive income taxes are effectively paid out to the corporation only when businesses distribute dividends to shareholders. Provincial corporate taxes on interest and capital gains are not refundable, and the federal refund rate is only partial. Dividends earned from publicly traded corporations can effectively flow to shareholders at the lower eligible dividend tax rate even if the investment was originally sourced from retained earnings taxed at the preferential small business tax rate. Capital gains on passive investments at the corporate level benefit from the partial inclusion rate and the refund of taxes, giving them an advantage over RRSPs or TFSAs. Furthermore, the integration mechanism described above breaks down for CCPC income earned

4 A dividend tax credit is given on grossed up dividends.

5 Whether the income is "passive" or "active" depends on the facts. For instance, dividends from another company in which the investor has an interest greater than 10 percent of the value of all shares are not "passive."

6 A combined federal-provincial tax rate of around 50 percent for interest and the taxable portion of capital gains, and a federal rate of 38.3 percent on portfolio dividends.

7 The refundable taxes are tracked in the "Refundable Dividend Tax on Hand" (RDTOH) pool, which can be viewed as an account that accumulates refundable tax paid by a private company on its investment and dividend income.

8 At a refund rate of 30.7 percent for interest and the taxable portion of capital gains, and at a refund rate of 38.3 percent for portfolio dividends.

9 To the extent that capital cost allowances replicate accurately the economic life of underlying asset. 
at the general corporate tax rate, because only 72 percent of such income can flow to owners at the appropriate, eligible dividend rate, while the rest, including the passive investment income, attracts the higher ineligible dividend tax rate.

But despite very imperfect integration, the key point is that, measured against a consumption-tax benchmark, the current CCPC tax regime has many unobjectionable features.

\section{The Proposed Regime}

The proposed regime would end passive investment income-tax refundability for CCPCs - ie., taxes paid on investment income in a CCPC would no longer be tracked and refunded upon dividend payments. Although there are other versions of proposed changes, this is seemingly the one the government favours. Private corporations - and by extension their owners - would be taxed on their passive investment income on the same basis as if they were individual investors in fully taxable accounts. There would be diminished incentives to defer business consumption, and less income and business saving available for spending on capital equipment. The same is true of small business income retained for personal purposes - there will be greater incentives for immediate personal consumption of business income rather than saving it for retirement or other purposes.

\section{IS THE CURRENT REGIME EQUITABLE?}

Fairness in tax policy usually means one or both of two things: individuals should pay more taxes as their incomes rise ("vertical equity"), and individuals in similar situations should pay similar taxes ("horizontal equity"). The Finance proposals are mostly concerned with the latter: high earners should bear the same tax burden on their passive investment income whether they earn business income through a private corporation or whether they are employees.

So, is the current system unfair? To answer this question, we need to compare the tax burden on passive investments made from retained corporate earnings by a private corporate owner to that of a salaried individual.

\section{Tax Illustrations}

Compare a small business owner and a salaried individual, both subject to the top marginal tax rate on personal income, and both having $\$ 100,000$ before-tax to invest over 10 years (Table 1$).{ }^{10}$ Suppose each invests for 10 years in one or another of three portfolios: an interest-only portfolio of bonds; a dividend-only portfolio of publicly traded shares; and a capital gain-only portfolio of shares. For simplicity, all securities yield a 3 percent rate of return. ${ }^{11}$

Salaried individuals can invest in an RRSP or a TFSA, in both of which investment income accumulates tax free. For the exact same investments, an RRSP and a TFSA will achieve the same after-tax outcome provided that the tax rates on the way in and on the way out are the same.

10 The $\$ 100,000$ of employment or corporate earnings is before income taxes are deducted or deferred. For simplicity, the tax illustrations assume no intertemporal tax rate changes, and taxpayers remain in the same personal income tax brackets through time.

11 This rate of return is aligned with the interest illustrations in Finance Canada's white paper (Canada 2017). The results shown in Table 1 and in the Appendix are sensitive to rate of return assumptions. A higher rate of return would compound the size of the gaps between the various options, but would not change the overall directions of the gaps and the main conclusions drawn from the results. 


\begin{tabular}{|c|c|c|c|c|c|c|c|}
\hline \multirow{2}{*}{\multicolumn{2}{|c|}{ Regime }} & \multicolumn{2}{|c|}{ Interest } & \multicolumn{2}{|c|}{ Dividends } & \multicolumn{2}{|c|}{ Capital Gains } \\
\hline & & Wealth (\$) & Gap & Wealth (\$) & Gap & Wealth (\$) & Gap \\
\hline \multirow{2}{*}{ Salary Income } & Taxable Account & 56,632 & - & 59,177 & - & 61,476 & - \\
\hline & $R R S P / T F S A$ & 65,763 & $+16 \%$ & 65,763 & $+11 \%$ & 65,763 & $+7 \%$ \\
\hline \multirow{2}{*}{$\begin{array}{l}\text { Current Regime: } \\
\text { CCPC Income }\end{array}$} & Small Bus. Rate & 60,838 & $+7 \%$ & 66,522 & $+12 \%$ & 69,988 & $+14 \%$ \\
\hline & General Rate & 56,204 & $-1 \%$ & 60,933 & $+3 \%$ & 63,825 & $+4 \%$ \\
\hline \multirow{2}{*}{$\begin{array}{l}\text { Proposed Regime: } \\
\text { CCPC Income }\end{array}$} & Small Bus. Rate & 56,068 & $-1 \%$ & 58,324 & $-1 \%$ & 60,937 & $-1 \%$ \\
\hline & General Rate & 52,227 & $-8 \%$ & 55,193 & $-7 \%$ & 56,284 & $-8 \%$ \\
\hline
\end{tabular}

They may also invest their after-tax earnings in personal taxable accounts, perhaps because they need quick access to the funds, because they have exhausted all of their RRSP/TFSA and pension plan room, or they expect to earn dividends or capital gains that are more tax-effective outside an RRSP or TFSA.

Corporate owners, on the other hand, may retain earnings in the corporation, pay corporate income taxes, and invest the after-tax proceeds in a taxable corporate investment account.

The simulation of after-tax earnings and investment returns - assuming yearly proceeds are reinvested every year, and deducting all federal and provincial taxes, including personal, corporate, and investment income taxes when applicable - yields wealth available for personal consumption, for each portfolio. Detailed results by province are provided in Appendix; here, we show the cross-province average to make the main points (Table 1 ).

\section{Results under the Current Regime}

Not surprisingly, the current regime for passive investment income out of retained earnings at the small business tax rate yields an advantage over salary income invested in a taxable account for all types of returns (Table 1 ). The advantage is the greatest for capital gains, followed by dividends (eligible) and interest. But compared to RRSPs/ TFSAs, only small-business capital gains yield a significantly better tax outcome. The interest income illustration, in particular, yields much lower net wealth available for personal consumption when invested in a corporate taxable account rather than in an RRSP/TFSA. A portfolio well balanced among interest, dividends, and capital gains, therefore, would yield a similar result whether invested from retained earnings at the smallbusiness rate in a CCPC, or whether invested out of wages before tax in an RRSP or after tax in a TFSA. 
CCPC investment income from earnings taxed at the general corporate rate, on the other hand, yields a much worse result. The gap between the wealth accumulated in a personal taxable account and in the CCPC subject to the general rate is minimal for interest, and only slightly positive for dividends and capital gains. There is certainly no tax advantage from passively reinvesting CCPC earnings when taxed at the general rate: the outcome is much worse than RRSP/TFSA investments. This result is primarily driven by the imperfect corporate/personal tax integration of general-rate earnings upon distribution to shareholders.

\section{Results under the Proposed Regime}

The proposed regime would eliminate the refundable portion of corporate taxes on passive investment income, and subject dividends distributed to corporate owners from the capital dividend account ${ }^{12}$ to personal taxes. The new regime would, as intended, bring business owners taxed at the small-business rate to an outcome broadly equivalent to salaried employees investing in a taxable personal account (Table 1).

However, the proposed regime would lead to a much worse outcome for CCPC retained income that gets taxed at the general corporate tax rate: net wealth available for consumption would be about 8 percent inferior ${ }^{13}$ to personal income invested in a taxable account (Table 1).

\section{The Verdict on Equity}

As illustrated in Table 1, under the current regime, the tax differences between passively reinvested corporate earnings and salaries depend on the type of corporate earnings (taxed at the general corporate rate or the small business rate), and on the composition of passive investment income among interests, dividends, and capital gains. Although the precise gaps vary by province (as shown in the Appendix), the tax advantages of earning passive investment income within a CCPC are the greatest for capital gains and dividends. The advantages are much less for interest income. And practically no tax advantages exist for CCPC income taxed at the general rate.

Overall, on a balanced portfolio of interest, capital gains, and dividends, the after-tax outcome for a small-business-rate passive investor would compare to that of an employee investing in an RRSP or a TFSA. Considering that additional administration, accounting, and tax compliance costs need to be incurred in corporate accounts, one could reasonably conclude that passively reinvested small-business earnings receive a tax treatment similar to that of RRSP/TFSAs in a variety of possible portfolio compositions.

Where's the unfairness? Tax rules limit the amount of retirement saving individuals can do annually, while small business owners are not limited in the amount of earnings they may retain in their corporation. ${ }^{14}$ But a focus on the

12 The portion of capital gains (one half) excluded from taxable income at the corporate level.

13 Assuming that rules constraining accumulations in the General Rate Income Pool (GRIP) for CCPCs would not change (the white paper is unclear on this point). An anonymous reviewer, however, pointed out that the spirit behind the proposals suggests that the GRIP rules would most likely change. If that were the case, net wealth available for consumption would still be inferior, but by a smaller margin (6 percent on average instead of 8 percent).

14 Most individuals are not constrained by the current RRSP contribution limit - the fact that some individuals with highly fluctuating incomes are constrained by annual limits may constitute an unfairness of its own. 


\section{Figure 1: Maximum Tax-Assisted Career Accumulations of Retirement Wealth - Assuming a $\$ 150,000$} Salary at Retirement

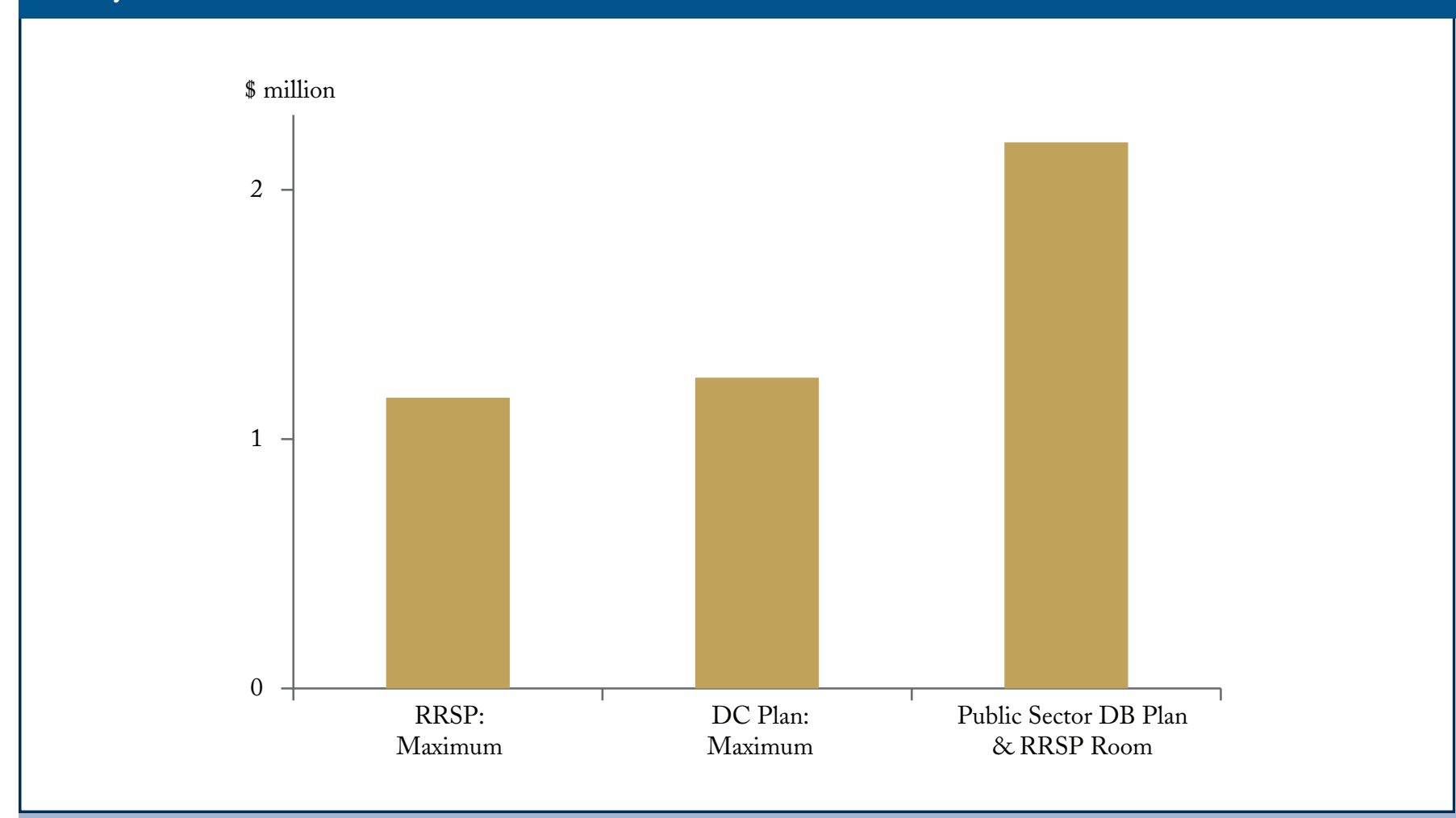

Source: Pierlot and Siddiqi (2011). Actuarial valuations assuming a 35-year career under current tax rules.

ways in which the tax system largely parallels a consumption-based tax points to a very different response to this unfairness: increasing the limits on tax-deferred saving in RRSPs. ${ }^{15}$

Some Canadians already have much greater opportunities to build tax-deferred saving than typical RRSP holders. Most public-sector employees and MPs have relatively generous defined-benefit pensions that are indexed to inflation and based on a final/best earnings formula.

Pierlot and Siddiqi (2011) compared the maximum tax-deferred saving opportunities available in DB plans, Defined Contribution (DC) plans, and RRSPs, using an actuarial modelling tool that incorporates Canadian tax rules for retirement. They showed that current tax rules are preventing workers saving for retirement in their RRSP or DC plan from accumulating even half the retirement wealth of some public-sector DB pension plan members. A DB plan member earning $\$ 150,000$ at the end of a 35-year career could theoretically retire with a tax-deferred retirement wealth of about $\$ 2.2$ million, compared to up to about $\$ 1.2$ million for an otherwise-equivalent worker saving through an 
RRSP who - in an impossibly best-case scenario - would have made the maximum contribution permitted in each and every year of his or her career (Pierlot and Siddiqi 2011, p. 11). ${ }^{16}$ Updated for current yields and longevity, the advantage to government DB plans is even greater (Robson 2017 forthcoming). ${ }^{17}$

Clearly, the amount of available tax-assisted investment room for retirement is already vastly unequal. The proposed regime, effectively restricting many business owners to personal $\mathrm{RRSP} / \mathrm{DC}$ room in order to tax-effectively save for retirement, would not level the field. ${ }^{18}$ At a minimum, the proposals if enacted should be accompanied by a reform of the tax-assisted retirement savings system to level the playing field, and enable business owners to pay themselves the same pension at the same cost as members of the most comprehensive DB pension plans.

\section{POTENTIAL ISSUES}

\section{Potential Negative Impact on Entrepreneurship and Risk Taking}

Passive corporate investments are not used solely for personal savings and retirement; in fact, in many cases the primary objective is to save for future productivity-enhancing capital-equipment purchases and other active-business investments. The proposed regime could subject passive investment income to additional taxation, leaving less available for reinvestment. Assuming the refunds of taxes to the corporation are triggered and reinvested, and a 5 percent portfolio rate of return, small business owners would have 6 percent less to reinvest in their businesses after 5 years, and 13 percent less after 10 years. ${ }^{19}$ One could also factor in potential higher borrowing costs if retained earnings are not there to protect lenders. Canada's business investment per worker is already at its worst level compared to the United States in more than a quarter century (Robson et al. 2017a). Context matters here: we should think twice before putting sand in the wheels of business investments.

The new regime would give CCPC owners an incentive to take the money out of the corporation and invest in personal registered accounts whenever possible, whether the savings are for future business reinvestment or personal use. But restricting

16 In addition, federal public servants' and Members of Parliament's pension plans are fully backed by taxpayers. Small business owners or incorporated professionals who wanted similar protection from inflation and default would have to invest their retirement savings in the federal government's inflation-protected long-term debt obligations, or real-return bonds (RRB). Amassing the stock of RRBs required to fund the same retirement annuity would require some 50 percent of their annual incomes - and to match MPs, more than 70 percent: vastly above the 18 percent annual RRSP contribution limit (up to \$26,010). (See Laurin and Robson 2017.)

17 In particular, all pension calculations in Pierlot with Siddiqi (2011) were based on actuarial assumptions in effect under guidelines from the Canadian Institute of Actuaries. Today, in 2017, under new updated guidelines, actual DB valuations are likely to be at least 30 percent more.

18 Under pension tax rules, corporate owners who are employees of the CCPC can also set up an Individual Pension Plan (IPP). An IPP provides for a greater potential accumulation of tax-deferred retirement wealth than an RRSP or a DC plan. However, IPPs require expensive setup and administration costs. There is also a legislated requirement to make required annual contributions, which may not be a good fit for entrepreneurs with fluctuating income, losses, or expecting less prosperous years (Booker 2007). Finally, under section 8504(1)(a)(i) of the Income Tax Regulations, an "IPP must assume a normal retirement age of 65 and may utilize a career average earnings formula, but not a final/best earnings approach (Booker 2007, p. 11-35).” A career-average benefit formula restricts the amount of retirement wealth that can be accumulated compared to the final- or best-years approach of most public-sector DB plans.

19 A lower rate of return would decrease this variation while a higher rate would increase it. 
tax-effective savings for future business capital investment to room available in personal RRSPs (which should be for retirement purposes) would certainly act as a disincentive to risk taking and entrepreneurship. Moreover, investments such as real estate and shares in private companies are not eligible within RRSPs or TFSAs.

Another important consideration is that income from entrepreneurship is inherently riskier and less stable than income from employment. Small business owners generally experience greater year-to-year income fluctuation than salaried employees, and indeed may suffer losses. They are thus susceptible to having taxable income fluctuating between different tax brackets over many years. Since personal income tax rates in Canada are now steeply graduated, they would stand to face a larger total tax burden on risky entrepreneurial earnings over a multi-year period than others with steadier incomes (Gordon and Wen 2017 , forthcoming). One way to smooth outcome over time is to defer the personal taxation of the income by retaining a portion in the CCPC. Such income smoothing would become more expensive under the new regime, potentially negatively impacting entrepreneurship.

\section{Grandfathering and Other'Transitional Issues}

The new rules would be an important and disruptive change for existing business owners who had planned their affairs by combining their savings for corporate and personal (retirement) purposes under one roof. Some grandfathering of the old rules for existing business owners would therefore make sense.

One grandfathering alternative would be that corporations keep their existing accumulated pool of refundable taxes, until they are all refunded. But since all new passive returns would fall under the new system, corporate investors willing to benefit from the grandfathering would need to sell their passive assets now, before the new regime comes into force, thus realizing gains and maximizing their pool of refundable taxes - but potentially creating a massive selloff on capital markets.

A better alternative would be to grandfather not only the existing stock of refundable taxes, but also the underlying assets. The result would be the opposite of a selloff. It would give corporations the incentive to hold on to existing assets as long as possible so as not to lose the tax benefits on these assets. Selling an existing asset for a more profitable investment opportunity would require that the expected after-tax return on a new investment be superior to the after-tax return of the grandfathered asset - an unlikely scenario.

A more reasonable alternative would be to grandfather the existing assets and all reinvested proceeds from the trade of these assets, thereby creating a separate pool of passive investment funds administered under the old rules alongside all other passive investments falling under the new rules. Since the current pool of passive investment income is estimated at over $\$ 26$ billion, ${ }^{20}$ running both systems concurrently would be administratively complex, and would open the door to even more arbitrage and tax-planning activities.

But notwithstanding administrative complexity, grandfathering would need to take into account the potential for business owners not having accumulated as much RRSP contribution room as they potentially would have under the new system. Some entrepreneurs may have mostly paid themselves dividends over the years to cover personal consumption, instead of salaries. Because dividends do not create RRSP contribution room, these business owners would have to now save for retirement under the new system having accumulated potentially much less unused 
contribution room than they could have, in retrospect, had they planned their affairs differently. It is easy to imagine a situation where over the years most of the corporate savings went to active business reinvestment instead of retirement savings, and where most personal consumption was funded through dividends as opposed to salaries. Changing the rules on people who have planned in this fashion and, thanks to annual RRSP contribution limits, cannot adjust would be grossly unfair.

\section{Potential Alternative Reforms}

Alternatives to the proposed regime would need to level the playing field with respect to taxation of passive investment income between owners of incorporated businesses and other Canadians. It would also have to do this without imposing additional economic costs in terms of reduced risktaking and entrepreneurial activity, and without wasting more resources on tax compliance and administration, as well as tax-planning activities which have no further benefits.

The best way to level the retirement playing field would be to give everyone the same tax-deferred savings possibilities, whether they are incorporated business owners or unincorporated self-employed, private- or public-sector employees, or newcomers to Canada. Small business owners are at particular risk of not having enough DC/RRSP contribution room because they are at a greater risk of having incurred investment losses and bankruptcies, experienced periods of highly fluctuating incomes or made RRSP withdrawals before retirement to fund capital investments in their businesses.

Pierlot and Siddiqi (2011) proposed "that Canada's annual, income-based tax limits on retirement saving be discarded and replaced with a uniform, inflation-indexed lifetime accumulation limit of $\$ 2$ million - the value of pensions now accumulated by high-income workers with career membership in generous DB pension plans, especially in the public sector." A lifetime limit would bring equity among all workers with respect to potential career retirement wealth accumulation. It could be introduced along with the new proposed regime for passive investment income.

Even with a lifetime tax-assisted limit, however, the proposed regime would still subject passive investment income - on corporate retained earnings - to additional taxation, leaving fewer funds available for active reinvestment in the business carried out by the same or another corporation. It would also leave in many situations private corporations ineligible for the small business rate much worse off.

An additional step could be to target the application of the new regime only to owners of certain corporations - for example, "incorporated professionals" have been widely identified in the media to supposedly be the primary target of the proposed regime - who could then make use of the lifetime accumulation limit proposed here. In principle, however, it is hard to justify targeting one broad category of CCPC over the other. Another approach, therefore, could be to push aside the proposals and instead make every CCPCs pay the general corporate tax rate on active business income (with the adoption of complementary measures ${ }^{21}$ to mitigate the negative impact on economic growth and innovation). As Table 1 shows, passive investment income sourced from earnings subject to the general tax rate does not enjoy favourable tax treatment.

21 As suggested by Robson et al. (2017b), the elimination of the small business deduction could be accompanied by the establishment of an allowance for corporate equity relieving ordinary corporate returns from corporate income tax, and/ or targeting the small business deduction to nascent, growing firms instead of to all firms that are "small." These additional complementary measures would improve the tax climate for productivity-enhancing business investments. 


\section{CONCLUSION}

The stated objective of the tax proposals with respect to passive investment income earned by CCPCs is to provide "fairness" between employed individuals and business owners earning business income through private corporations. Basic tax illustrations show that CCPC income earned at the general corporate tax rate and reinvested passively in the corporation enjoys no significant tax advantages over other saving options.

Business owners earning income taxed at the small-business tax rate and saving it in the corporation for future personal consumption enjoy a tax treatment pretty much on par with others saving through an RRSP or a TFSA. Benchmarking against a consumption tax base makes clear that mitigating the impact of cascading taxes - doubleor triple-taxation of saving - by deferring tax inside a company is not dissimilar to avoiding tax cascading in tax-assisted retirement saving plans or a TFSA.

But the field with respect to tax-assisted saving opportunities is already largely unequal. Career DB pension plan participants, particularly in the public sector, retire with a career tax-deferred retirement wealth worth multiples of the amounts that it is practically feasible to accumulate in RRSPs.

The proposed regime, effectively restricting many business owners to personal RRSP/DC contribution room, ${ }^{22}$ would not level the playing field. Small business owners earning a good income would have insufficient tax-assisted savings room to build a pension with a value similar to that of career public servants, for example. Someone wishing to privately match the pension granted to MPs, for instance, would have to put aside over 70 percent of his/her annual income - an impossible feat under current RRSP contribution limits.
And small-business savings serve a much greater purpose than simply funding future personal consumption. Retained earnings can be used to fund future productivity-enhancing capital equipment purchases, business acquisitions, and other business investments. They can also be used to lower current borrowing costs. The proposed system would not distinguish between funds saved for personal or business purposes, and therefore would leave less money available for future reinvestments hindering risk taking activities and business growth.

If the federal government proceeds with changes along the lines it has outlined, it should level the playing field by bringing everyone under the same consumption tax base, without deterring entrepreneurial activity, and without creating rules that will lead to more resources being wasted on compliance and administration costs. Reforms would need to be accompanied by a lifetime taxassisted savings accumulation limit, in lieu of the current system of annual limits. The limit would be set to match the savings opportunities of those currently enjoying the most generous pensions, so that anyone willing to fund for themselves an equivalent arrangement could do so, including small business owners. In addition, the proposed regime could be either targeted to a limited number of CCPCs - those more susceptible to use it as a private savings vehicle - or abandoned in favour of subjecting all CCPCs to the general corporate tax rate (with complementary measures aimed at reducing the potential negative impacts on entrepreneurship and risk taking). This new system would be fairer for everyone, and would impose a lighter burden on the economy. 


\section{APPENDIX}

\section{Appendix Table - Illustrated After-Tax Net Wealth Available for Personal Consumption after Ten Years on a $\$ 100,000$ Gross Earnings Investment}

\begin{tabular}{|c|c|c|c|c|c|c|}
\hline \multirow{3}{*}{ Jurisdiction } & \multicolumn{2}{|c|}{$\begin{array}{l}\text { Employed Individual - } \\
\text { Reinvested Salary Income }\end{array}$} & \multicolumn{4}{|c|}{$\begin{array}{c}\text { Corporate Investor - Reinvested } \\
\text { Retained Earnings }\end{array}$} \\
\hline & \multirow{2}{*}{$\begin{array}{l}\text { Taxable } \\
\text { Account }\end{array}$} & \multirow{2}{*}{ RRSP/TFSA } & \multicolumn{2}{|c|}{$\begin{array}{l}\text { Taxed at the } \\
\text { Small Business Rate }\end{array}$} & \multicolumn{2}{|c|}{$\begin{array}{c}\text { Taxed at the } \\
\text { General Business Rate }\end{array}$} \\
\hline & & & $\begin{array}{l}\text { Current } \\
\text { Regime }\end{array}$ & $\begin{array}{l}\text { Proposed } \\
\text { Regime }\end{array}$ & $\begin{array}{l}\text { Current } \\
\text { Regime }\end{array}$ & $\begin{array}{l}\text { Proposed } \\
\text { Regime }\end{array}$ \\
\hline NL & 56,302 & 65,449 & 60,776 & 55,998 & 49,923 & 46,056 \\
\hline PEI & 56,209 & 65,355 & 59,279 & 54,611 & 55,358 & 51,569 \\
\hline NS & 52,757 & 61,820 & 56,993 & 52,505 & 49,505 & 45,925 \\
\hline NB & 53,671 & 62,761 & 58,095 & 53,534 & 56,986 & 53,242 \\
\hline 2C & 53,658 & 62,747 & 57,549 & 53,045 & 54,575 & 50,530 \\
\hline $\mathrm{DN}$ & 53,370 & 62,452 & 58,510 & 53,933 & 54,885 & 50,927 \\
\hline MB & 57,495 & 66,658 & 61,025 & 56,248 & 55,506 & 51,610 \\
\hline$K$ & 61,043 & 70,220 & 66,485 & 61,284 & 62,536 & 58,167 \\
\hline$A B$ & 60,706 & 69,884 & 64,555 & 59,501 & 60,755 & 56,538 \\
\hline BC & 61,110 & 70,287 & 65,113 & 60,023 & 62,015 & 57,710 \\
\hline Average & 56,632 & 65,763 & 60,838 & 56,068 & 56,204 & 52,227 \\
\hline
\end{tabular}

Source: Author's calculations. Assumptions described in the text on pp. 6-7. For simplicity, refunds of investment income taxes to the CCPC are assumed to be triggered at the end of the investment period when proceeds are paid out. Immediate triggering of the refunds, when possible, would leave more funds to be reinvested. In these illustrations, the timing of the trigger does not play a significant role. Under the proposed regime, it is assumed here that rules constraining accumulations in General Rate Income Pool (GRIP) for CCPCs would not change (the white paper is unclear on this point). 


\section{Table A2: Dividend-Only Portfolio}

\begin{tabular}{|c|c|c|c|c|c|c|}
\hline \multirow{3}{*}{ Jurisdiction } & \multicolumn{2}{|c|}{$\begin{array}{l}\text { Employed Individual - } \\
\text { Reinvested Salary Income }\end{array}$} & \multicolumn{4}{|c|}{$\begin{array}{c}\text { Corporate Investor - Reinvested } \\
\text { Retained Earnings }\end{array}$} \\
\hline & \multirow{2}{*}{$\begin{array}{l}\text { Taxable } \\
\text { Account }\end{array}$} & \multirow{2}{*}{ RRSP/TFSA } & \multicolumn{2}{|c|}{$\begin{array}{c}\text { Taxed at the } \\
\text { Small Business Rate }\end{array}$} & \multicolumn{2}{|c|}{$\begin{array}{c}\text { Taxed at the } \\
\text { General Business Rate }\end{array}$} \\
\hline & & & $\begin{array}{l}\text { Current } \\
\text { Regime }\end{array}$ & $\begin{array}{l}\text { Proposed } \\
\text { Regime }\end{array}$ & $\begin{array}{l}\text { Current } \\
\text { Regime }\end{array}$ & $\begin{array}{l}\text { Proposed } \\
\text { Regime }\end{array}$ \\
\hline NL & 57,765 & 65,449 & 64,973 & 58,591 & 53,319 & 48,295 \\
\hline PEI & 59,125 & 65,355 & 65,952 & 57,309 & 60,775 & 55,099 \\
\hline NS & 54,728 & 61,820 & 62,357 & 55,100 & 53,784 & 48,743 \\
\hline NB & 56,897 & 62,761 & 65,258 & 55,848 & 62,864 & 56,960 \\
\hline QC & 55,837 & 62,747 & 61,769 & 54,979 & 58,366 & 52,857 \\
\hline ON & 55,654 & 62,452 & 63,317 & 55,849 & 59,041 & 53,466 \\
\hline MB & 59,676 & 66,658 & 66,730 & 58,333 & 60,159 & 54,479 \\
\hline SK & 64,257 & 70,220 & 72,721 & 63,462 & 67,774 & 61,370 \\
\hline $\mathrm{AB}$ & 63,691 & 69,884 & 70,866 & 61,706 & 66,020 & 59,785 \\
\hline $\mathrm{BC}$ & 64,136 & 70,287 & 71,280 & 62,064 & 67,231 & 60,873 \\
\hline Average & 59,177 & 65,763 & 66,522 & 58,324 & 60,933 & 55,193 \\
\hline
\end{tabular}

Source: Author's calculations. Assumptions described in the text on pp. 6-7. For simplicity, refunds of investment income taxes to the CCPC are assumed to be triggered at the end of the investment period when proceeds are paid out. Immediate triggering of the refunds, when possible, would leave more funds to be reinvested. In these illustrations, the timing of the trigger does not play a significant role. Under the proposed regime, it is assumed here that rules constraining accumulations in General Rate Income Pool (GRIP) for CCPCs would not change (the white paper is unclear on this point). 


\section{Table A3: Capital Gain-Only Portfolio}

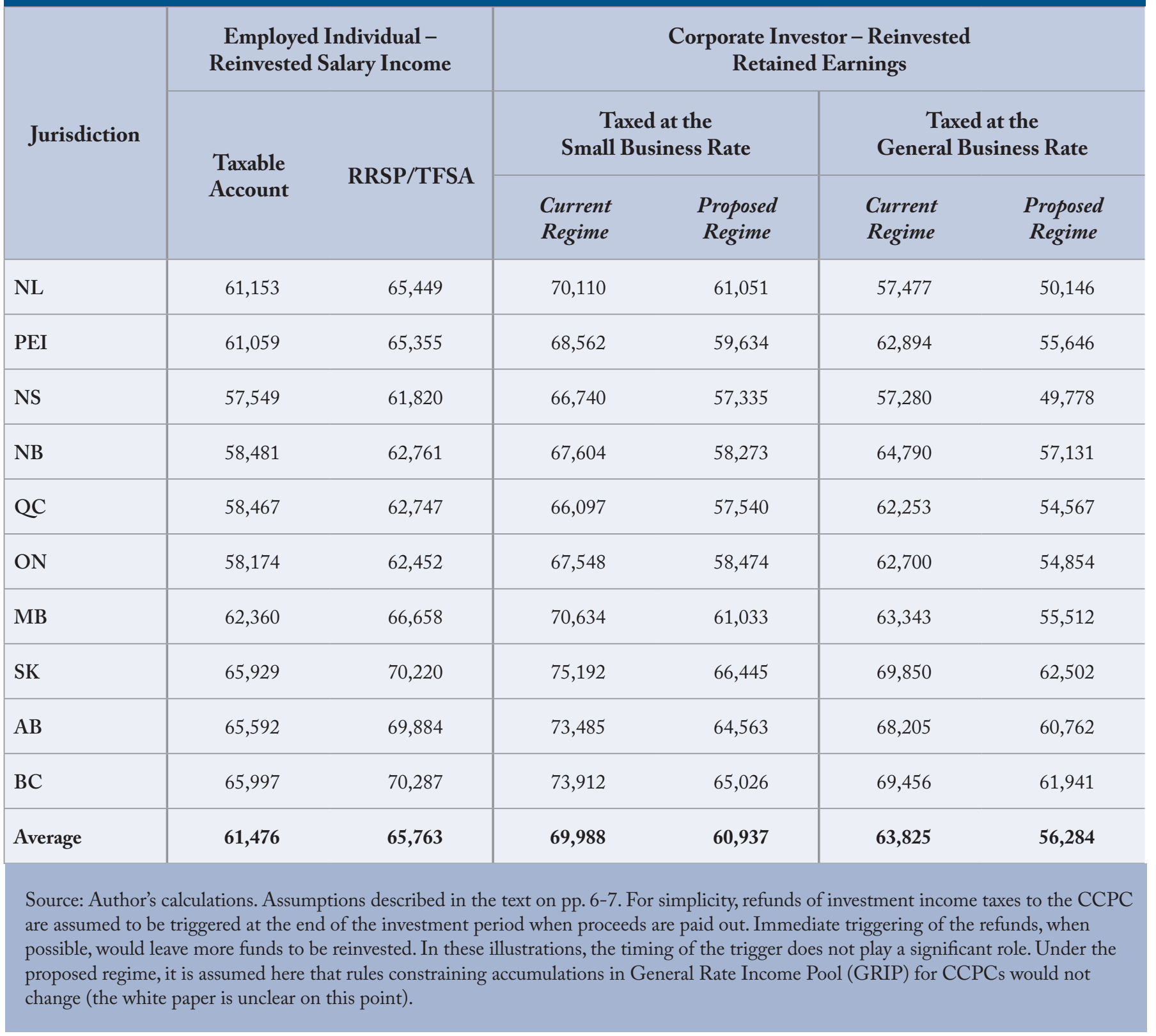




\section{REFERENCES}

Booker, Jill. 2007. Comprehensive Practices in Risk and Retirement Planning. 3rd Edition. CCH Canadian Limited.

Canada. 2017. "Tax Planning Using Private Corporations." Department of Finance Canada. July.

Kesselman, J. Rhys, and Peter S. Spiro. 2014. Challenges in Shifting Canadian Taxation Toward Consumption. Canadian Tax Journal 62:1.

Laurin, Alexandre, and Robson, William B.P. 2017. "Premium Compensation: The Ballooning Cost of Federal Government Employees." E-Brief. Toronto: C.D. Howe Institute. May 11.

Gordon, Daniel V., and Jean-François Wen. 2017. A Question of Fairness: Time to Reconsider IncomeAveraging Provisions. Commentary (forthcoming). Toronto: C.D. Howe Institute. October.

Pierlot, James, with Faisal Siddiqi. 2011. Legal for Life: Why Canadians Need a Lifetime Retirement Saving Limit. Commentary 336. Toronto: C.D. Howe Institute. October.
Robson, William B.P.. 2017 (forthcoming). Rethinking Limits on Tax-Deferred Retirement Savings in Canada. Commentary (forthcoming). Toronto: C.D. Howe Institute.

Robson, William B.P., Aaron Jacobs, and Benjamin Dachis. 2017a. "Equipment Failure: Feeble Business Investment Costs Canadians their Competitive Edge.” E-Brief. Toronto: C.D. Howe Institute. March 24.

Robson, William B.P., Alexandre Laurin, and Rosalie Wyonch. 2017b. Getting Real: A Shadow Federal Budget for 2017. Commentary 470. Toronto: C.D. Howe Institute. February.

Robson, William B.P., and Alexandre Laurin. 2017. Hidden Spending: The Fiscal Impact of Federal Tax Concessions. Commentary 469. Toronto: C.D. Howe Institute. February.

Thivierge, Vincent, and Alex Laurin. 2017. "Capital Gains Widely Enjoyed, Not Just by Top Earners.” C.D. Howe Institute: Intelligence Memo. March 17. 
NOTES: 
NOTES: 
NOTES: 


\section{ReCEnt C.D. Howe Institute Publications}

September 2017 Dachis, Benjamin, Blake Shaffer, and Vincent Thivierge. All's Well that Ends Well: Addressing End-of-Life Liabilities for Oil and Gas Wells. C.D. Howe Institute Commentary 492.

September 2017 Marchand, Joseph. Thinking about Minimum Wage Increases in Alberta: Theoretically, Empirically, and Regionally. C.D. Howe Institute Commentary 491.

September 2017 Le Pan, Nicholas. Opportunities for Better Systemic Risk Management in Canada. C.D. Howe Institute Commentary 490.

September 2017 Naglie, Harvey. Not Ready for Prime Time: Canada's Proposed New Securities Regulator. C.D. Howe Institute Commentary 489.

September 2017 Aptowitzer, Adam "No Need to Reinvent the Wheel: Promoting Donations of Private Company Shares and Real Estate." C.D. Howe Institute E-Brief.

September 2017 Mahboubi, Parisa, and Colin Busby. "Closing the Divide: Progress and Challenges in Adult Skills Development among Indigenous Peoples.” C.D. Howe Institute E-Brief.

August $2017 \quad$ John Richards. Red Flags for Educators: Lessons for Canada in the PISA Results. C.D. Howe Institute Commentary 488.

August 2017 Wyonch, Rosalie. Bits, Bytes, and Taxes: VAT and the Digital Economy in Canada. C.D. Howe Institute Commentary 487.

August 2017 Trebilcock, Michael. “Ontario’s Green Energy Experience: Sobering Lessons for Sustainable Climate Change Policies.” C.D. Howe Institute E-Brief.

August 2017 Mahboubi, Parisa. The Power of Words: Improving Immigrants' Literacy Skills. C.D. Howe Institute Commentary 486.

July 2017 Li, Qing. “Education Quality and Immigrants' Success in the Canadian Labour Market.” C.D. Howe Institute E-Brief.

July 2017 Koeppl, Thorsten V., and James C. MacGee. Mortgage Insurance Deductibles: An Idea Whose Time Hasn't Come. C.D. Howe Institute Commentary 485.

\section{SUPPORT THE INSTITUTE}

For more information on supporting the C.D. Howe Institute's vital policy work, through charitable giving or membership, please go to www.cdhowe.org or call 416-865-1904. Learn more about the Institute's activities and how to make a donation at the same time. You will receive a tax receipt for your gift.

\section{A REPUTATION FOR INDEPENDENT, NONPARTISAN RESEARCH}

The C.D. Howe Institute's reputation for independent, reasoned and relevant public policy research of the highest quality is its chief asset, and underpins the credibility and effectiveness of its work. Independence and nonpartisanship are core Institute values that inform its approach to research, guide the actions of its professional staff and limit the types of financial contributions that the Institute will accept.

For our full Independence and Nonpartisanship Policy go to www.cdhowe.org. 

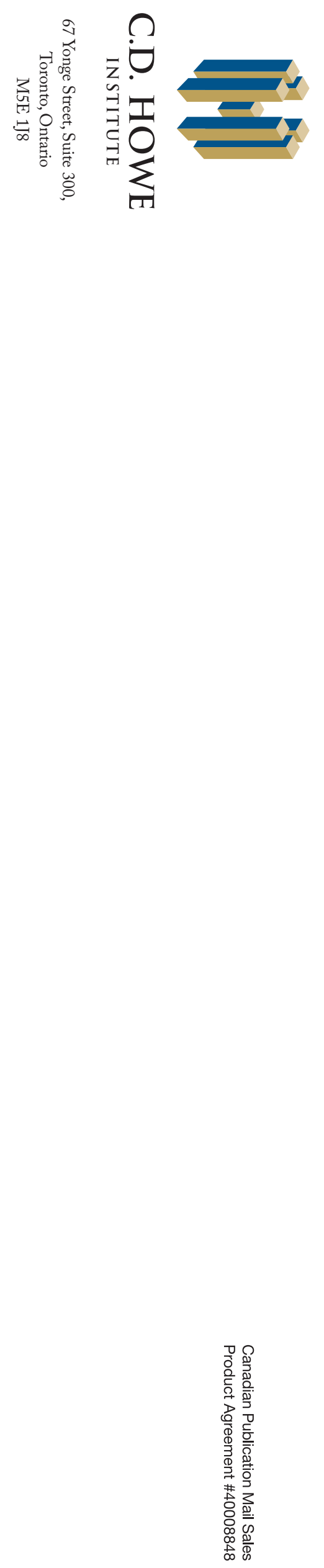